\title{
T cell immunosenescence, hypertension, and arterial stiffness
}

\author{
Hee Tae Yu, Eui-Cheol Shin \\ Laboratory of Immunology and Infectious Diseases, Graduate School of Medical Science and Engineering, KAIST, Daejeon, Korea
}

Immunosenescence is a concept used to describe the age-associated deterioration of immune function, characterized by functional and phenotypic changes on both cellular and systemic levels [1,2]. Immunosenescence in elderly people is associated with an increased susceptibility to infectious diseases, impaired response to vaccinations, and increased incidence of cancer and autoimmunity [3-5]. During immune aging, senescent $\mathrm{T}$ cells accumulate in the peripheral $\mathrm{T}$ cell pool $[2,6,7]$. By repetitive antigenic stimulation of $\mathrm{T}$ cells, their telomeres are shortened [8] and the expression of CD28, a co-stimulatory molecule, is lost [9]. In humans, cytomegalovirus (CMV) is known to be one of the most important antigens that cause repetitive $\mathrm{T}$ cell stimulation $[10,11]$. As a result of such repetitive stimulation, CD28 $8^{\text {null }} \mathrm{T}$ cells accumulate during the immune aging process [12]. Similarly, the expression of CD57 antigen on T cells is currently considered to be another surrogate marker of the replicative senescence of T cells [13]. CD57 is a terminally sulfated glycan carbohydrate epitope, and $\mathrm{CD} 57^{+} \mathrm{T}$ cells showed an inability to proliferate after antigenic stimulation in vitro and a high susceptibility to activation-induced apoptosis [14,15] (Figure 1). Compared to $\mathrm{CD} 28^{+} \mathrm{CD} 57^{-} \mathrm{T}$ cells, $\mathrm{CD} 57^{+} \mathrm{T}$ cells produce more proinflammatory cytokines and exert greater cytotoxicity [16]. These senescent $\mathrm{CD} 57^{+} \mathrm{T}$ cells are known to be associated with a number of inflammatory diseases in humans [17-19].

Recent studies have reported the association between senescent T cells and various cardiovascular diseases. Accelerated telo-

\section{Correspondence: Eui-Cheol Shin}

Laboratory of Immunology and Infectious Diseases, Graduate School of Medical Science and Engineering, KAIST, 291 Daehak-ro, Yuseong-gu, Daejeon 305-701, Korea

Tel: +82-42-350-4236, Fax: +82-42-350-4240, E-mail: ecshin@kaist.ac.kr

Received: Apr 30, 2014, Accepted: May 12, 2014, Published: May 23, 2014 This article is available from: http://e-epih.org/

(C) 2014, Korean Society of Epidemiology

(C) This is an open-access article distributed under the terms of the Creative Commons Attribution License (http://creativecommons.org/licenses/by/3.0/), which permits unrestricted use, distribution, and reproduction in any medium, provided the original work is properly cited. mere shortening in T cells and peripheral blood mononuclear cells (PBMCs) was seen in patients with atherosclerosis [20] and myocardial infarction [21]. Higher frequencies of $\mathrm{CD} 8^{+} \mathrm{CD} 28^{\text {null }}$ $\mathrm{CD} 7^{+} \mathrm{T}$ cells were associated with an increased prevalence of carotid artery lesions in a study of human immunodeficiency virus-infected patients [22]. Liuzzo et al. [23] reported that the number of $\mathrm{CD} 4{ }^{+} \mathrm{CD} 28^{\text {null }} \mathrm{T}$ cells was significantly greater in the peripheral blood of patients with unstable angina (UA) compared to the number in those with chronic stable angina. The frequency of $\mathrm{CD} 4{ }^{+} \mathrm{CD} 28^{\text {null }} \mathrm{T}$ cells correlated with the number of interferon (IFN)- $\gamma$-secreting T cells, suggesting that $\mathrm{CD} 28^{\text {null }} \mathrm{T}$ cells could be the main source of IFN- $\gamma$ production in patients with UA. Furthermore, it was shown that a higher frequency of $\mathrm{CD} 4{ }^{+} \mathrm{CD} 28^{\text {null }} \mathrm{T}$ cells was associated with the recurrence of acute coronary events in UA patients [24]. Patients who experienced recurrent acute coronary events had a higher frequency of $\mathrm{CD} 4{ }^{+} \mathrm{CD} 28^{\text {null }} \mathrm{T}$ cells than those with a single episode during 4 years of follow-up. Another study found that the number of $\mathrm{CD} 4^{+} \mathrm{CD} 28^{\text {null }} \mathrm{T}$ cells is expanded in patients with diabetes mellitus, and this expansion is associated with poor glycemic control [25]. The presence of these senescent $\mathrm{T}$ cells also correlates with the occurrence of a first cardiovascular event and with worse outcomes after an acute coronary syndrome.

Senescent $\mathrm{T}$ cells have been studied not only in conjunction with atherosclerotic disease but also with hypertension [26]. Patients with hypertension had an increased frequency of circulating $\mathrm{CD} 8^{+}$cytotoxic $\mathrm{T}$ cells bearing surface markers of replicative senescence, which is characterized by the loss of CD28 and the acquisition of CD57. These individuals also had higher circulating levels of the C-X-C chemokine (CXC) receptor type 3 chemokines, such as CXCL9, CXCL10, and CXCL11. The frequency of $\mathrm{CD}^{+} \mathrm{T}$ cells producing perforin, granzyme $\mathrm{B}, \mathrm{IFN}-\gamma$, or tumor necrosis factor (TNF)- $\alpha$ was increased in the peripheral blood of hypertensive patients than in that of healthy controls. However, there was no difference in the frequency of regulatory $\mathrm{T}$ cells and IL-17-producing $\mathrm{CD}^{+} \mathrm{T}$ cells between the two groups. Immunohistochemical staining of kidney sections from patients with hypertensive nephrosclerosis revealed an in- 


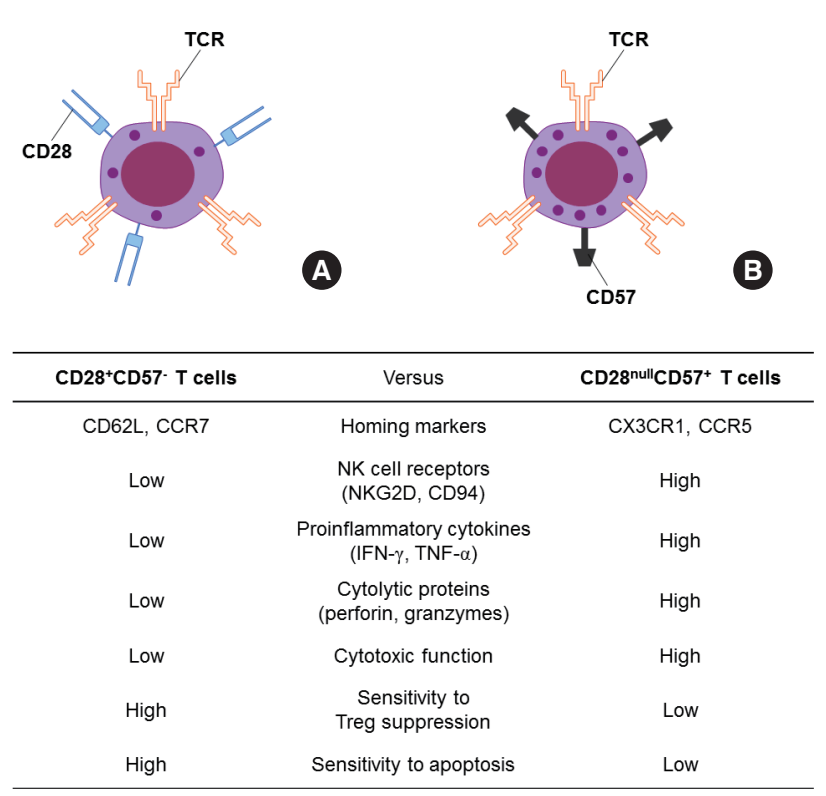

Figure 1. Comparison of CD28 ${ }^{+} \mathrm{CD} 57^{-} \mathrm{T}$ cells $(\mathrm{A})$ and $\mathrm{CD} 28^{\text {null }} \mathrm{CD} 57^{+}$ senescent $T$ cells (B). INF, interferon; TNF, tumor necrosis factor.

crease in $\mathrm{CD}^{+}$and $\mathrm{CD} 8^{+} \mathrm{T}$ cells, along with greater expression of CXCL11, in the proximal and distal tubules compared with that in normotensive controls.

Arterial stiffening is one of the major mechanisms for the pathogenesis of hypertension [27], and arterial stiffness is increased in the presence of established cardiovascular risk factors including aging [28]. The degree of arterial stiffness is known to be associated with various markers of inflammation $[29,30]$, suggesting a certain role for immunological factors in increasing arterial stiffness. In this regard, we recently studied whether $\mathrm{T}$ cell immunosenescence is associated with arterial stiffness evaluated by pulse wave velocity (PWV) in Koreans. We found that the frequency of $\mathrm{CD} 57^{+}$cells in the $\mathrm{CD} 8^{+} \mathrm{T}$ cell population was independently correlated with the PWV, even after adjusting for age, sex, systolic blood pressure, diabetes mellitus history, smoking history, body mass index, creatinine, high-density lipoprotein cholesterol, and high sensitivity C-reactive protein (data not published). We also studied CMV-specific $\mathrm{T}$ cell responses since CMV is a major driving antigen for the replicative senescence of $\mathrm{T}$ cells $[10,11]$. The frequency of CMV-specific IFN- $\gamma$ or TNF-a secretion or the cytotoxic function of CD8 ${ }^{+} \mathrm{T}$ cells was positively correlated with PWV in multivariate analysis (data not published). Recently, the significance of CMV infection in increased arterial stiffness was also reported by Wall et al. [31]. They demonstrated that arterial stiffness was higher in the CMVseropositive group than in the CMV-seronegative group among patients with chronic kidney disease.

In summary, $\mathrm{T}$ cell senescence can be evaluated by the fre- quency of CD28 $8^{\text {null }} \mathrm{T}$ cells or CD57 ${ }^{+} \mathrm{T}$ cells in PBMCs. CMV is a major factor accelerating $\mathrm{T}$ cell senescence. $\mathrm{T}$ cell senescence is related to cardiovascular diseases such as atherosclerosis, acute myocardial infarction, and hypertension. It is also associated with increased arterial stiffness. The roles of $\mathrm{T}$ cell senescence and CMV infection in cardiovascular disease need to be validated in large cohort studies, and the mechanism by which senescent $\mathrm{T}$ cells contribute to the pathogenesis of cardiovascular disease requires further investigation.

\section{ACKNOWLEDGEMENTS}

This study was supported by a grant of the Korean Health Technology R\&D Project, Ministry of Health \&Welfare, Republic of Korea (HI13C0715).

\section{CONFLICT OF INTEREST}

The authors have no conflicts of interest to declare for this study.

\section{REFERENCES}

1. Walford RL. The immunologic theory of aging. Immunol Rev 1969; 2:171.

2. Linton PJ, Dorshkind K. Age-related changes in lymphocyte development and function. Nat Immunol 2004;5:133-139.

3. Goodwin K, Viboud C, Simonsen L. Antibody response to influenza vaccination in the elderly: a quantitative review. Vaccine 2006;24: 1159-1169.

4. Ostan R, Bucci L, Capri M, Salvioli S, Scurti M, Pini E, et al. Immunosenescence and immunogenetics of human longevity. Neuroimmunomodulation 2008;15:224-240.

5. Lindstrom TM, Robinson WH. Rheumatoid arthritis: a role for immunosenescence? J Am Geriatr Soc 2010;58:1565-1575.

6. Nikolich-Zugich J. T cell aging: naive but not young. J Exp Med 2005; 201:837-840.

7. Nikolich-Zugich J. Ageing and life-long maintenance of T-cell subsets in the face of latent persistent infections. Nat Rev Immunol 2008; 8:512-522.

8. Monteiro J, Batliwalla F, Ostrer H, Gregersen PK. Shortened telomeres in clonally expanded CD28-CD8+ T cells imply a replicative history that is distinct from their CD28+CD8+ counterparts. J Immunol 1996; 156:3587-3590.

9. Effros RB. Loss of CD28 expression on T lymphocytes: a marker of replicative senescence. Dev Comp Immunol 1997;21:471-478.

10. Akbar AN, Fletcher JM. Memory T cell homeostasis and senescence during aging. Curr Opin Immunol 2005;17:480-485.

11. Pawelec G, Derhovanessian E, Larbi A, Strindhall J, Wikby A. Cytomegalovirus and human immunosenescence. Rev Med Virol 2009; 19:47-56.

12. Weng NP, Akbar AN, Goronzy J. CD28(-) T cells: their role in the 
age-associated decline of immune function. Trends Immunol 2009; 30:306-312.

13. Focosi D, Bestagno M, Burrone O, Petrini M. CD57+ T lymphocytes and functional immune deficiency. J Leukoc Biol 2010;87:107-116.

14. Vogel M, Kowalewski HJ, Zimmermann H, Janetzko A, Margolis RU, Wollny HE. Association of the HNK-1 epitope with 5'-nucleotidase from Torpedo marmorata (electric ray) electric organ. Biochem J 1991;278:199-202.

15. Brenchley JM, Karandikar NJ, Betts MR, Ambrozak DR, Hill BJ, Crotty LE, et al. Expression of CD57 defines replicative senescence and antigen-induced apoptotic death of CD8+ T cells. Blood 2003; 101:2711-2720.

16. Dumitriu IE, Araguás ET, Baboonian C, Kaski JC. CD4+ CD28 null $\mathrm{T}$ cells in coronary artery disease: when helpers become killers. Cardiovasc Res 2009;81:11-19.

17. Maeda T, Yamada H, Nagamine R, Shuto T, Nakashima Y, Hirata G, et al. Involvement of CD4+,CD57+ T cells in the disease activity of rheumatoid arthritis. Arthritis Rheum 2002;46:379-384.

18. Palmer BE, Blyveis N, Fontenot AP, Wilson CC. Functional and phenotypic characterization of CD57+CD4+ T cells and their association with HIV-1-induced T cell dysfunction. J Immunol 2005;175:84158423.

19. Palmer BE, Mack DG, Martin AK, Maier LA, Fontenot AP. CD57 expression correlates with alveolitis severity in subjects with beryllium-induced disease. J Allergy Clin Immunol 2007;120:184-191.

20. Samani NJ, Boultby R, Butler R, Thompson JR, Goodall AH. Telomere shortening in atherosclerosis. Lancet 2001;358:472-473.

21. Brouilette S, Singh RK, Thompson JR, Goodall AH, Samani NJ. White cell telomere length and risk of premature myocardial infarction. Arterioscler Thromb Vasc Biol 2003;23:842-846.

22. Kaplan RC, Sinclair E, Landay AL, Lurain N, Sharrett AR, Gange SJ, et al. T cell activation and senescence predict subclinical carotid artery disease in HIV-infected women. J Infect Dis 2011;203:452-
463.

23. Liuzzo G, Kopecky SL, Frye RL, O'Fallon WM, Maseri A, Goronzy $\mathrm{JJ}$, et al. Perturbation of the T-cell repertoire in patients with unstable angina. Circulation 1999;100:2135-2139.

24. Liuzzo G, Biasucci LM, Trotta G, Brugaletta S, Pinnelli M, Digianuario $\mathrm{G}$, et al. Unusual CD4+CD28null T lymphocytes and recurrence of acute coronary events. J Am Coll Cardiol 2007;50:1450-1458.

25. Giubilato S, Liuzzo G, Brugaletta S, Pitocco D, Graziani F, Smaldone $\mathrm{C}$, et al. Expansion of CD4+CD28null T-lymphocytes in diabetic patients: exploring new pathogenetic mechanisms of increased cardiovascular risk in diabetes mellitus. Eur Heart J 2011;32:12141226.

26. Youn JC, Yu HT, Lim BJ, Koh MJ, Lee J, Chang DY, et al. Immunosenescent $\mathrm{CD} 8+\mathrm{T}$ cells and $\mathrm{C}-\mathrm{X}-\mathrm{C}$ chemokine receptor type 3 chemokines are increased in human hypertension. Hypertension 2013; 62:126-133.

27. Kannel WB, Wolf PA, McGee DL, Dawber TR, McNamara P, Castelli WP. Systolic blood pressure, arterial rigidity, and risk of stroke. The Framingham study. JAMA 1981;245:1225-1229.

28. Blacher J, Pannier B, Guerin AP, Marchais SJ, Safar ME, London GM. Carotid arterial stiffness as a predictor of cardiovascular and allcause mortality in end-stage renal disease. Hypertension 1998;32: 570-574.

29. Mahmud A, Feely J. Arterial stiffness is related to systemic inflammation in essential hypertension. Hypertension 2005;46:1118-1122.

30. Tuttolomondo A, Di Raimondo D, Pecoraro R, Serio A, D'Aguanno G, Pinto A, et al. Immune-inflammatory markers and arterial stiffness indexes in subjects with acute ischemic stroke. Atherosclerosis 2010;213:311-318.

31. Wall NA, Chue CD, Edwards NC, Pankhurst T, Harper L, Steeds RP, et al. Cytomegalovirus seropositivity is associated with increased arterial stiffness in patients with chronic kidney disease. PLoS One 2013;8:e55686. 